\title{
CROSS AND ROMAN LEGION: POPULAR IMAGINARY IN THE FIRST CENTURY PALESTINE
}

Luiz Alexandre Solano Rossi ${ }^{1}$

\begin{abstract}
From the year $63 \mathrm{BCE}$ the new imperial order arrives in Palestine. An empire desired by the gods and considered eternal as the gods themselves are. Nevertheless, the eternity of the Empire passes through instruments of violence against the peoples subjugated in the present. Thus, the cross and the Roman legion will become symbols in the social imaginary of the Palestine's peasants. Imaginary that is constructed from images present in the daily routine. Crosses and soldiers were present in the Palestinian scenario to remind any peasants of their vulnerability and at the same time to reaffirm the perennity of an empire deified by force.
\end{abstract}

\section{Key words}

Cross; violence; empire; new world order, legion.

\section{Resumo}

A partir do ano 63 a.C. a nova ordem imperial chega na Palestina. Um império desejado pelos deuses e considerado eterno como os próprios deuses o são. No entanto a eternidade do Império passa por instrumentos de violência contra os povos subjugados no presente. Assim, a cruz e a legião romana se tornarão símbolos no imaginário coletivo dos camponeses na Palestina. Imaginário que se constrói a partir de imagens presente no próprio cotidiano. Cruzes e soldados estavam presentes no cenário da Palestina para relembrar a qualquer camponês de sua vulnerabilidade e, ao mesmo tempo, reafirmar a perenidade de um Império divinizado pela força.

\section{Palavras-chave}

Cruz; violência; império; nova ordem mundial; legião.

\footnotetext{
${ }^{1}$ Assistant Professor, Pontifical Catholic University of Paraná/Uninter, Curitiba, Brazil. email: luizalexandrerossi@yahoo.com.br
} 


\section{To Professor Funari}

It was the year 2003, when I was preparing a project to start postdoctoral research. Having finished the project, I was missing a researcher to supervise my work. It was precisely at this time that a friend researcher kindly gave me the electronic address of Professor Pedro Paulo Funari. Until that moment I did not know him personally. After all, we were from distinct areas of knowledge, that is, he was from the field of History and I was from the Bible.

I sent the first e-mail presenting myself and expressing my goals with the possible research I proposed, but a series of doubts and fears accompanied each word. I thought that a researcher of his greatness, nationally and internationally renowned and a reference in his field, would never bother to reply to another message that arrived in his mailbox. What a surprise for me when, the next day, Professor Funari's response was already in my mailbox. An answer I read with a big smile! To my delight, he accepted to be my supervisor and proposed a working meeting for the next few days in São Paulo.

From that moment on, prof. Funari became my post-doctoral research supervisor at UNICAMP for the next two years. A time extremely profitable both for the experience of friendship and for the academic production that followed. However, more than a supervisor, prof. Funari became a friend of mine. So, if the postdoctoral research ended, the friendship, the influence and the dedication to the research that I learned walking in the footsteps of prof. Funari remain until today. The multiplication of thanks would never be enough from me. Therefore, I respond to the friendship of Prof. Funari with a double portion of amity and affection, ad aeternum.

\section{Introduction}

The advance of the Roman Empire toward Palestine may be dated back to 63 BC, when Pompey succeeded in taking Jerusalem without much trouble. An achievement that will make Palestine remain subdued to the Roman Eagle and whose rule would feed the hatred of the people for many centuries. The new Roman imperial order rehearsed its first steps by bringing the legions and the cross as tools for establishing the new imperial order.

Cross and legion quite possibly filled the imagery of peasants in Palestine. They presented themselves as symbolic representations based 
on a daily life marked by both physical brutality and economic violence. Along the roads, towns and cities where the peasants' eyes could contemplate the multiple and countless crosses piercing the land with violence and/or when the ears could hear the sound of the legionary soldiers' boots marching in a rhythm of conquest, the peasants would know that the imaginary had become real.

In speaking of the "imaginary" of the people of Palestine I resort to the concept of imaginary established by Hilário Franco Júnior (1998: 23) as "a set of visual and verbal images generated by a society (or part of it) in its relation to itself, with other human groups and with the universe in general." In this way, it is possible to conclude that every imaginary - one must stress the need to perceive the many possible imaginaries and not fall into the error of reducing to "a single imaginary" - is eminently collective and therefore could not be confused with individual psychic activity or even to the sum of imaginations.

Palestine could be described as an ensemble of dominated cities subjected to the Roman power. It is possible to assert that most of the Jewish history in Palestine (and the provinces of Galilee, Samaria, and Judea) of the first century involved protest and resistance against Roman provocations and oppression (Horsley, 1987: 33). The main victims of the Roman expansionist policy were precisely the peasants. For them, Roman domination fundamentally meant heavy taxation and, more than that, a serious threat to their existence, since many of them were expelled from their lands (Horsley, Hanson, 1995: 43).

It is not possible to minimize the period of Roman domination. In it we find the appropriate scenario for the emergence of continuous struggles, guerrillas and popular uprisings. Palestine could be described as one of the greatest points of rebellion against Roman imperial expansion. We could also add that in Palestine of the first century the economic condition of the population was in dizzying fall, reflecting in the deterioration of the quality of life. The most vulnerable people lived surrounded by instability and poverty. Horsley (1987: 29) describes that violence in the region was "institutionalized" because it had been determined by the imperial conquest. He claims that the Romans possessed their self-legitimating ideology of "defending their friends and allies" and of bringing "civilization" and "Peace" to the rest of the world. Nevertheless, the imperial conquest was marked by the abusive use of violence, reaching entire populations either by murder or by slavery.

Rocha (2004: 245) presents a real first-century scenario under the rule of the Roman Empire: 
By the middle of the first century, it is estimated a population between 50 and 80 million inhabitants for the Roman Empire, of which about $90 \%$ lived in the countryside. But the land, the main source of survival for the population of the Empire, including that of Palestine, was very poorly distributed. In the Italian peninsula and in the Provinces most of the productive lands were in the hands of a minority. In Egypt we find the case of 42 farmers sharing the same house. Seneca indicates that the poor constituted the greater part of the population and that the situation was unlikely to be changed.

Moxnes wrote about that (36-37): "Every description of the ancient economy must start from the fact that it was based on agriculture. Agriculture was not just another sector of the economy; it was the very basis of that economy". Of course, from the new imperial order, the subsistence farming will go through a period of frank decline, thereby opening up social, economic, and also political instability. Periodic military operations in various parts of Galilee and the extra economic burden imposed on the peasantry by the Roman tribute and the collection of special taxes had a disastrous effect on the Galilean peasants. The taxes demanded of the people a great effort that led, irremediably, to the misery. The practice of collecting taxes benefited a certain social group in Rome that lived at the expense of taxes. Tax collection, coupled with other forms of oppression, produced an increase in the number of poor, marginalized, sick, among others, who became hostages of the structures of Roman power. Through these policies, Galilee saw the number of sick, unemployed and landless farmers grow.

Crossan (2004: 201-202) makes an important distinction between merchant agrarian empire that characterizes the new imperial order and traditional agrarian empires, a model that prevailed in Palestine before the arrival of the Roman Empire:

In the traditional agrarian empire, the aristocracy takes the surplus product of the peasant class; in the merchant agrarian empire, the aristocracy takes the land of the peasant class. The first one devours the effort and the product of the peasants, the second their own identity and dignity. In the traditional agrarian empire, the land is a family heritage to be preserved by the peasant class. In the merchant agrarian empire, land is a business commodity to be exploited by the aristocracy.

It seems obvious to conclude from all the cited data that most of those who opposed Rome always belonged to the rural class, thus indicating the reasons that led to the peasant revolts in Palestine between the years 66 and 70. But it is also possible to highlight the extremely severe oppression of the Jewish population of Palestine by the Romans and the local aristocracy itself, which included the high priests. Rocha (2004: 246) states that at the end of the Augustan era (ca. 14), the true dominant layer 
consisted of approximately 160 people. A permanent army of 350,000 to 400,000 men guaranteed the status quo, rendering ineffective any revolt against the rule of the Romans and local leaders, their allies.

\section{The superhuman strength of the legions}

Throughout the literature we find many references not only regarding the military dexterity of Rome as well as its formation. In this sense, Koester (2005: 6) states that Vespasian, during the winter of 66, gathered three legions and several auxiliary troops; at another time, he provides information, albeit generic, regarding the logistic ability and military technique, declaring that in one of Vespasian's raids the siege lasted "several weeks." Josephus (Wars, Book II), for his part, insists on describing the power of the Roman army by recording on many occasions: "Varus left one of the three legions in the city" and still "the Romans prevailed with their warlike experience" (Wars 2.47); "Petronius went from Antioch to Judea with three legions and with many allies of Syria" (Wars, 2.186); "Florus went to Jerusalem with an army of cavalry and infantry to intervene there with Roman weapons and to plunder the city with terror and threats" (Wars 2.295) and concerning the campaign of Cestius, he informs us that "he transferred from Antioch the twelfth full legion, two thousand soldiers selected from the other legions, his infantry troops and four cavalry wings" (2.498).

However, one of the greatest questions concerning the Roman army remains unanswered: no existing source affirms the precise number of men in the legions. In this way, we could approach Crossan (1995: 147), who states that a legion consisted of 6.000 men or even Southern (2007: 99) which indicates that it is possible that the number of legionaries was different in the provinces and in different times and that, therefore, the majority of the researchers end up opting for a legionary force between 5.000 and 6.000 men. In addition to the legions, there were auxiliary troops recruited in the provinces and a fleet. Each legion comprised 10 cohorts and 6 centuries constituted a cohort. Originally, all legionaries were recruited from Roman citizens, but once the source of human resources was in the process of being reduced, the distinction between citizens and non-citizens was completely ignored.

Regarding the chain of command, Koester (2005: 237) informs us that a legion was commanded by a legate (legatus) of the senatorial class. To him were subordinate six military tribunes, the first of which came from the senate, and the others from the equestrian order, from which also came 
the commanders of the auxiliary troops. These officers served only for limited periods, but the equestrians could serve for a longer period of time. The permanent officers of the army were the centurions, ordinary citizens for whom military service was a lifelong profession. A special subdivision of the army was the imperial guard, the Praetorians, who had become an elite body and also served as a kind of military academy. The Praetorians, a corporation with approximately 4.500 men and commanded by two mayors (praefectus), were the only unit of the army stationed on Italian soil.

From the point of view of the political-military strategy, it was of the utmost importance that most legions were stationed in the border provinces. After all, the administration of these provinces by the emperor was closely related to his military imperium. The emperor's political strength was guaranteed by the presence and strength of the legions, who could sometimes appoint the emperor.

The Roman legionary force was considered lethal. Two examples are significant: 1) The governor named Varus mobilized three legions and auxiliary troops to crush revolts on Jewish land. When he arrived in Jerusalem, he crucified, according to the account of Josephus (War 2.75), "two thousand rebels." The mass crucifixions marked the beginning and the end of the first Roman-Jewish war. 2) Early in the summer of 66 AD, Florus, Roman governor of the Jewish land, ordered his troops to attack within the city. The report of Josephus (War 2.306-308) speaks for itself:

Many of the peaceful citizens were detained and brought before Florus, who first ordered them to be whipped and then crucified. The total number of victims on that day, including women and children, since they were not worthy of forgiveness, amounted to three thousand and six hundred. The calamity was aggravated by the unprecedented aspect of the cruelty of the Romans. For Florus ventured on that day to do what no one had ever tried before, that is, to whip before his court and to nail to the cross men of knighthood, men who, if Jews by birth, were at least invested with that Roman dignity.

The Roman army in march should impress and fuel the despair of the populations that were in its way. But it must be pointed out that there was a certain order in the military march. According to Josephus (2009b, War, 3.115-126), in the year 67, General Vespasian, who was not yet an emperor, marched towards Galilee and displayed his army in the sight of the enemy to infuse them with fear, with the following order:

a) Auxiliary forces and lightly armed archers to check the ground and discover ambushes;

b) Infantry and cavalry detachment with heavy weapons; 
c) Ten men from each century with their own equipment and with the instruments necessary to measure the layout of the camp;

d) Afterwards, they followed the engineers to check the roads, to flatten the difficult paths and to cut trees that restricted the access;

e) The transport of the luggage of Vespasiano and of his officers protected by the cavalry;

f) Behind, Vespasian himself rode with a detachment of infantry and cavalry, as well as his own personal guard;

g) Then, the cavalry proper of each legion;

h) Then, the mules carrying the siege machines;

i) Ahead, the officers followed: the commanders of the legions, the mayors and tribunes with guards;

j) Then, the banners went with the symbol of the eagle;

k) The trumpets followed the banners;

1) After the trumpets, there followed the phalanges with their troops distributed in rows of six with a centurion with the purpose of supervising them;

m) There followed the servants and the baggage;

n) At the back of the legions, there goes a large number of mercenaries protected by soldiers with heavy weapons and by a large number of cavalrymen.

The army stationed before the enemies presented itself as the very image of the terror and violence that was to come. However, soldiers eager to engage in combat followed well-defined battle tactics in order to break the enemy battle line, which can thus be described according to Webster (1985: 232):

1) In land battles, a force is directed to the center, with two side forces and a reserve one at the rear. The side and reserve forces must be strong enough to prevent any attack or maneuver off the flank;

2) An oblique battle line to the left side force remains in a defensive position, while the right side force advances to try to dominate the opponent's left flank. An opposition to this movement is to strengthen the left force with cavalry and reserves, but if both sides succeed on the battle front, they tend to move counterclockwise, whose effect would vary because of the nature of the ground;

3) The previous position is repeated, except that the left force becomes stronger and makes an attempt of a new movement that happens from the moment it is known that the enemy's right force is weakened; 
4) The two side forces advance together, leaving the center back. This movement can take the enemy by surprise and, consequently, leave their center exposed and demoralized;

5) Same tactic as above, but the center is hidden by archers and light infantry who can keep the enemy center distracted while the side forces battle;

6) A variation of tactic 2 where the center and left side are held back while the right side force tries a return movement. If the action succeeds, the left side, reinforced by the reserves, can advance and hope to complete the attack movement that would compress the center;

7) It is the use of the appropriate terrain on any of the flanks to protect them as suggested in tactic 2 .

The violence of the legions escapes understanding. Josephus himself reports that Titus' troops captured poorer Jews who were fleeing from Jerusalem to fetch food outside the walls and tortured, beaten, and crucified them before the eyes of the city's defenders. In one case, they cut off the hands of victims of torture and returned them, mutilated, to the city, as a means of coercing the inhabitants into surrender (War, 5.11,5). Words burdened with pain and violence such as whipping, torturing, burning eyes and maiming are part of Josephus' vocabulary in describing Roman military action (5.49.9).

When researching the Roman legion, it is not possible to overlook the text of Mark $(5,1-17)$ that symbolically portrays the superhuman strength of a legion from a very particular episode of Jesus' action in liberating the possessed of Gadara. An account that raises several questions and some of them become special: a) Does the episode reveal any relation between the oppression that the Roman Empire exerted on Palestine and the phenomenon of so many people possessed by the devil at the time of Jesus? b) would it be an unhealthy way of rebelling against Roman submission and the rule of the powerful? Even if we do not understand the healing of the demoniac Gerasene as strictly historical, it may be possible to state that the imaginary of the people of Palestine was filled by images of the oppression of Rome. Yes, we are probably facing the healing of an individual, but we can not and should not ignore the symbolism that the narrative brings within. Quite possibly, the symbolic character of the text incorporates and generates more meaning.

Consequently, it is possible to affirm that, in the face of episodes of the exorcisms of Jesus, and especially that of Gerasene, the simple people of Galilee would, from their collective imaginary, glimpse the rapid defeat of the Romans or, in Crossan's words (1994: 352) when he states that "the account is a summary of every Jewish revolutionary's dream" and in 
Soares' words (2002: 222) indicating that "the satanic presence is like the devastating occupation of the Roman troops." From the point of view of religious discourse, we could say that the violence of the Roman empire, through its legions, acquires a "diabolic" connotation.

According to the account, the devil is only one, but it is called "legion" because there are many. It is the same term to refer to the armed division of Rome that controlled Palestine with iron hand. It should be stressed that "knowing the name" of someone in that culture meant the pretension of dominating that person and being stronger than him. The impure spirit, therefore, in responding to Jesus, seeks to demonstrate all its power, and thereby, from the symbolic, to subdue the weakest. The demons expelled by Jesus enter into the swine that were considered "the most impure animals of all and the best that could define the Romans" (Pagola, 208). Chouraqui (1996: 93) is even more incisive in stating that "man is possessed by the devil as Israel by the Roman legions." And Bortolini goes in the same direction (2003: 105) in expressing that the "possessed is a symbol of a politically dominated people."

The text is narrated in search of its climax and, as a result, the pigs rush into the sea where "Jewish resistance wanted to see them submerged forever" (Pagola, 208). In this way, the ruin of the pigs would also mean the liberation from slavery under Roman power. Storniolo (1992: 89) ratifies the information: "the pig was also considered a sacred animal and one of the symbols of Roman power." The pig was precisely the symbol of the X Roman legion that controlled from Syria the Palestinian region (Chouraqui, 1996).

Listening to Jesus' discourse, listeners could think only of the Roman legion established in Damascus in charge of maintaining order in that region and guarantee respect for the Pax Romana. We must not forget that Rome had sent to Judea and Syria its best troops to keep the order which was constantly disturbed by the rebellious population (Chouraqui, 94). In the text of the gospel of Mark, therefore, the Roman legion assumes superhuman characteristics and, more than that, it assumes a profile that meets superhuman and nonhuman forces of evil.

\section{The cross: when violence reaches a state of savagery}

The crucifixion was and remained a political and military punishment of the Roman Empire. According to Crossan (2008: 138-39), the Roman crucifixion was an instrument to counteract what was considered state 
terrorism and its function was to prevent resistance or revolt, especially among the lower classes. Related to Jesus, it is possible to say that the Roman Empire rarely exerted its power without necessity. In this sense, quite possibly, the empire "did not crucify teachers or philosophers ... if Jesus had been just a matter of words or ideas, the Romans probably would have ignored him" (Crossan, 2008: 15). Much more than words, it was Jesus' actions that bothered the spread of Pax Romana.

One of the greatest trumps of the Roman military was the crucifixion. It was used as an instrument to terrorize the subjugated peoples and thus to subject them to the imperial regime. The cross evoked necessarily - we can not think of it in a neutral way - the terror of torture and punishment for slaves and peoples resistant to Roman rule. Therefore, it is noticed that the cross has a very characteristic social horizon, that is, in it and for it are intended the agitators.

Horsley and Hanson (1985: 44) add that the Roman armies in their advance over the Jewish territories treated the inhabitants with brutality in order to induce the people to submit. According to the authors, "repeatedly, Roman armies have completely burned down and destroyed cities and slaughtered, crucified or enslaved their populations." One of the most notable examples is remembered by Josephus when he recorded that "when Cassius conquered Tariqa in Galilee, he enslaved about 30,000 men and later enslaved the people of important regional cities like Gofna, Emmaus, Lydda and Tamna" (Josephus apud Horsley, 1995: 44).

In the Roman world, therefore, crucifixion is fully crowned with political significance. Elliot (2004: 169) states that, as a means of capital punishment for heinous crimes, crucifixion was the "supreme Roman penalty" ", but almost always inflicted on the lower classes. It was the typical punishment for slaves as an instrument of deterrence (Hengel, 1978).

Crossan (1995: 54), in a reference to Tacitus, shows the description of the Roman Empire from General Calgacus' vision before his fatal encounter with the military power in northeastern Scotland. It is an exemplary text:

Looters of the world, now that the earth is not enough for their devastating hands, they exploit even the sea: if the enemy has riches, they have greed; if he is poor, they are ambitious; Neither the East nor the West satisfied them; They are the only people of humanity who contemplate with the same passion the scarcity - poor lands - and the abundance - rich lands. To plunder, to kill, to steal, to this they call erroneously empire: they bring desolation and call it peace. 
The cross was considered the most aggravating punishment that could be implemented. In terms of severity, Hengel contends (1978: 35), the crucifixion can only be compared to the games of popular entertainments in which the victims were thrown to the wild beasts. However, crucifixion was much more common because it did not require a popular feast to be performed with all its rigor. It was enough, indeed, enough wood to decorate the roads of the empire. And in that sense, the spectacle would follow a continuous flow, not depending, of course, on the calendar of festivals.

The perception of Dorothe Solle (p. 169) is essential in order to understand the social function of the cross in the first century:

The symbol of the religion of the slaves is the cross, a variant of the capital punishment reserved for slaves (...). It is in the first line a religious and political murder (...). It is above all a symbol of reality ... The cross is not a theological invention, but the response a thousand times given by the world to the attempt of freedom. We realize in it the ideology of the powerful, taken care of by the preservation of the established order, we see the cruelty and sadism of the soldiers, who collaborate with them and obey the orders.

The cross, in the first century, contrasts with freedom. In them - it will always be necessary to think of this instrument of torture in the plural since, after all, the crosses have spread absurdly on the roads of Palestine - not only hang bodies. There life stories remained that could not be completed, sacrificed on the altar of the empire. In the crosses of the Empire are found bodies of slaves and in the bodies, a hope of freedom.

\section{Conclusion}

Rome never acted alone in the subjugated countries. Next to it were the elites of the provinces as allies. The strategic alliance was certainly based on economic reasons, however, not purely. There was also an ideological reason that could be expressed in this way: the place and dominion of Rome on the world stage was the desire of the gods. Ideas such as this justified all efforts to subject the peoples to the power of the new imperial order, just as they justified the highly hierarchical society of the empire. While the elites of the provinces were enriched by the association with imperial power, the population suffered multiple forms of violence. To submit to Rome would be considered the same as submitting to the desire of the gods and, consequently, participating in their blessings.

In that same first century, Jesus will appear in the scenario of multiple violence as one of many Palestinians controlled by the power of the new 
imperial order. Jesus' actions and speeches will be produced in a situation of systemic injustice and structural evil in which a large percentage of sacrificed people was responsible for making the empire-building process possible. An empire that was built on the body of thousands of victims.

\section{Ancient Sources}

JOSEFO, F. Guerra dos judeus. Livro II. Curitiba: Juruá, 2009a.

JOSEFO, F. Guerra dos judeus. Livro III. Curitiba: Juruá, 2009b.

JOSEFO, F. Guerra dos judeus. Livro V. Curitiba: Juruá, 2009c.

\section{Bibliographic References}

BORTOLINI, J. O evangelho de Marcos. São Paulo: Paulus, 2003.

CHOURAQUI, A. Marcos. Rio de Janeiro: Imago, 1996.

CROSSAN, J. D. Jesus: uma biografia revolucionária. Rio de Janeiro: Imago, 1995.

CROSSAN, J. D. O essencial de Jesus: frases originais e primeiras imagens. Belo Horizonte: Jardim dos Livros, 2008.

CROSSAN, J.D. O Jesus histórico. Rio de Janeiro: Imago, 1994

CROSSAN, J.D. O Nascimento do Cristianismo. O que aconteceu nos anos que se seguiram à execução de Jesus. São Paulo: Paulinas, 2004.

ELLIOT, N. A mensagem antiimperial da cruz. In: HORSLEY, R. A. (Org.). Paulo e o Império: religião e poder na sociedade imperial romana. São Paulo: Paulus, 2004. p. 169-184.

FRANCO, H. Jr. Cocanha - a história de um país imaginário. São Paulo: Companhia das Letras, 1998.

HENGEL, M. Crucifixion: in the ancient world and the folly of the message of the cross. Fortress Press: Philadelphia, 1978.

HORSLEY, R. A. Jesus and the Spiral of Violence. San Francisco: Harper \& Row, 1987. 
HORSLEY, R. A. (Org.). Paulo e o império: religião e poder na sociedade imperial. São Paulo: Paulus, 2004.

HORSLEY, R. A.; HANSON, J. S. Bandidos, profetas e messias. São Paulo: Paulus, 1995.

KOESTER, H. Introdução ao Novo Testamento. São Paulo: Paulus, 2005. v. 1. PAGOLA, José A. Jesus - aproximação histórica. Petrópolis: Vozes, 2010.

SOARES, S.G. et al. Evangelho de Marcos. Vol. I:1-18. Petrópolis: Vozes, 2002

SOUTHERN, P. The Roman Army. Oxford: Oxford University Press, 2007

STORNIOLO, I. Como ler o evangelho de Lucas. São Paulo: Paulus, 1992.

WEBSTER, G. The Roman Imperial Army. New Jersey: Barnes \& Noble Books, 1985.

WENGST, C. Pax Romana: pretensão e realidade. São Paulo: Paulinas, 1991. 